\title{
Short-Range Movements of Hawksbill Turtles (Eretmochelys imbricata) from Nesting to Foraging Areas within the Hawaiian Islands ${ }^{1}$
}

\author{
Denise M. Parker, ${ }^{2,3,4}$ George H. Balazs, ${ }^{3}$ Cheryl S. King, ${ }^{5}$ Larry Katabira, ${ }^{6}$ and \\ William Gilmartin ${ }^{5}$
}

\begin{abstract}
Hawksbill sea turtles, Eretmochelys imbricata, reside around the main Hawaiian Islands but are not common. Flipper-tag recoveries and satellite tracking of hawksbills worldwide have shown variable distances in post-nesting travel, with migrations between nesting beaches and foraging areas ranging from 35 to $2,425 \mathrm{~km}$. Nine hawksbill turtles were tracked within the Hawaiian Islands using satellite telemetry. Turtles traveled distances ranging from 90 to $345 \mathrm{~km}$ and took between 5 to 18 days to complete the transit from nesting to foraging areas. Results of this study suggest that movements of Hawaiian hawksbills are relatively short-ranged, and surveys of their foraging areas should be conducted to assess status of the habitat to enhance conservation and management of these areas.
\end{abstract}

Hawksbill sea turtles, Eretmochelys imbricata (L.), are found in nearshore habitats in tropical regions of all oceans. Hawksbill turtles are listed as Critically Endangered in the International Union for Conservation of Nature (IUCN) Redbook (Hilton-Taylor 2000) and as Endangered under the Convention on International Trade in Endangered Species of Wild Fauna and Flora (CITES) (Washington, D.C., 1973) and the Endangered Species Act (U.S.A., 1973). The species has historically not been commonly harvested for consumption in the Pacific because the edible parts can sometimes be toxic (Fussy et al. 2007). Hawksbills in the Caribbean were not generally harvested for food before the

\footnotetext{
${ }^{1}$ Manuscript accepted 31 October 2008.

2 Corresponding author (e-mail: Denise.Parker@ noaa.gov).

${ }^{3}$ NOAA, National Marine Fisheries Service, Pacific Islands Fisheries Science Center, 2570 Dole Street, Honolulu, Hawai'i 96822-2396.

${ }^{4}$ Joint Institute for Marine and Atmospheric Research, 1000 Pope Street, MSB 312, Honolulu, Hawai' $i$ 96822.

${ }^{5}$ Hawai'i Wildlife Fund, P.O. Box 637, Pā'ia, Maui, Hawai'i 96779.

${ }^{6}$ Hawai'i Volcanoes National Park, P.O. Box 52, Hawai'i National Park, Hawai'i 96718 USA.
}

Pacific Science (2009), vol. 63, no. 3:371-382

(C) 2009 by University of Hawai'i Press

All rights reserved 1900s because of toxicity, but as hawksbill numbers declined due to harvesting for scutes (Carrillo et al. 1999, Campbell 2003) toxicity also seemed to decline. McClenachan et al. (2006) suggested that this reduction in toxicity may be connected to the declines in hawksbill numbers because of an increased availability of less-toxic sponges on which hawksbills prefer to forage. Large numbers of hawksbills were taken in the Pacific, mainly for their scutes, which are the thickest and most decorative of all sea turtle scutes. Items that were fashioned from bonding, shaping, and carving these scutes include combs, jewelry, decorative art, and tools (Kaeppler 1978, Canin 1991, Hainshwang and Leggio 2006). Despite international protection, hawksbills are still being harvested and exploited for curios and for tortoiseshell, known in Japan as bekko (Canin 1991, MSNBC News Service 2007). Knowledge of hawksbill movements, locations, and habitat usage of critical marine foraging habitats can aid state and local entities to develop effective protection and management schemes for the species.

Before 1995, few studies had been conducted using satellite telemetry to determine post-nesting movements of hawksbill turtles. Knowledge about population size and distribution of hawksbills was obtained mostly from flipper-tagging and recapture programs. Records of flipper-tag recoveries have indi- 
cated that many hawksbill populations within the Pacific and Atlantic oceans can have longdistance post-nesting movements. In the $\mathrm{Pa}$ cific, hawksbill turtles on breeding migrations moved between Australia and neighboring countries including Vanuatu, Solomon Islands, Papua New Guinea, and Indonesia. Migratory distances between foraging areas and nesting beaches ranged from 368 to $2,425 \mathrm{~km}$ (Miller et al. 1998, Bell et al. 1999). A flipper-tagged hawksbill that nested in the Solomon Islands was recovered in Papua New Guinea after the turtle had traveled an estimated straight-line distance of $1,400 \mathrm{~km}$ (Vaughan and Spring 1980). Post-nesting flipper-tag recoveries from the Caribbean provided movement distances of 1,400-2,000 $\mathrm{km}$ between nesting and foraging areas (Groshens and Vaughan 1994, Hillis 1994, Meylan 1999).

Since 1995, there has been increased usage of satellite telemetry worldwide to monitor the movements of post-nesting hawksbills. To date, much of the published turtle-tracking research has been in the Caribbean (Byles and Swimmer 1994, Hillis-Starr et al. 2000, Horrocks et al. 2001, Troëng et al. 2005, van Dam et al. 2008). These telemetry studies showed long-distance movements from Buck Island, St. Croix, U.S. Virgin Islands, to both Nicaragua $(1,400 \mathrm{~km})$ and Venezuela $(2,000$ $\mathrm{km})$, as well as short-distance movementsstaying within $300 \mathrm{~km}$ of Costa Rica and Buck Island, Virgin Islands. Conversely, satellite tracking of five post-nesting hawksbills in the Seychelles, Indian Ocean, in 1998 showed movements limited to $35-175 \mathrm{~km}$ (Mortimer and Balazs 2000).

Genetic studies of hawksbill turtles have been published mainly on Caribbean populations (Bass 1999, Mortimer et al. 2007). Pacific populations are currently being analyzed (Limpus and Miller 2008; NOAA Southwest Fisheries Science Center, unpubl. data).

The Hawaiian Archipelago (U.S.A.) extends for 2,450 km across an isolated region of the North Pacific $\left(19^{\circ} \mathrm{N}, 155^{\circ} \mathrm{W}\right.$ to $28^{\circ} \mathrm{N}$, $\left.178^{\circ} \mathrm{W}\right)$. The hawksbill, known as 'ea or honu'ea in the Hawaiian language, is rare in the Hawaiian Islands (Balazs 1978b, Balazs et al. 1994, National Marine Fisheries Service [NMFS] and U.S. Fish and Wildlife Service [USFWS] 1998). Hawksbill turtles do not currently nest or reside in the Northwestern Hawaiian Islands. Only one hawksbill has been recorded in that area: a juvenile found stranded alive at Pearl and Hermes Reef (2005, Pacific Islands Fisheries Science Center [PIFSC], unpubl. data).

Historically, hawksbills in Hawai'i were not eaten for food because of the toxicity and unpleasant taste of the meat, but the scutes were used for decorative inlay on important objects such as kāhili and for medicine, bracelets, combs, and fishing hooks (Buck 1957, Pukui and Elbert 1992, Rose et al. 1993).

Compared with the green turtle (Chelonia mydas), hawksbill sightings and strandings around the main Hawaiian Islands are relatively uncommon, and the majority of the sightings have consisted of immature turtles (Balazs 1978a, Keuper-Bennett and Bennett 2002, Chaloupka et al. 2008). To date, only two flipper-tagged adult hawksbill turtles have been recorded away from the nesting beaches. Both turtles were tagged nesting at Pōhue Bay, island of Hawaili. One was sighted in waters near Kahekili, Maui, a distance of $265 \mathrm{~km}$, shortly after the 2005 nesting season (W. Seitz and C. S. K., unpubl. data), and the second was sighted shortly after the 2008 nesting season near Honokōwai, Maui, a distance of $260 \mathrm{~km}$ (W. Seitz, U. KeuperBennett and P. A. Bennett, unpubl. data).

The number of adult female hawksbills has been estimated at less than 100, nesting at 20 beaches (Katahira et al. 1994, Mangel et al. 2000, King et al. 2007; L. K. and W. Seitz, unpubl. data). Previously, Kamehame, a small, remote beach located on the southeastern coast of the island of Hawai' $i$, was the main nesting beach in the Hawaiian Islands (Katahira et al. 1994). In addition to Kamehame, 12 other nesting beaches can be found on the island of Hawai' $i$. When combined, these beaches currently host the majority of hawksbill nestings in the Hawaiian Islands (Katahira et al. 1994; L. K. and W. Seitz, unpubl. data). Nesting beaches can also be found on 
other islands: two on the northeastern shore of O'ahu (Balazs 1978b), one on Moloka' $i$ (Balazs 1978b, pers. obs.), and four on Maui (Mangel et al. 2000, King et al. 2007).

Hawksbills are known to be spongivores (Meylan 1988), but details about the diet and foraging areas of the hawksbill in Hawai'i are still being studied. However, preliminary results to date indicate that both sponges and algae are an important part of hawksbill diets in Hawai'i (NOAA PIFSC, unpubl. data). Preliminary results from genetic analyses suggest that the Hawai'i nesting population includes only a few haplotypes (P. H. Dutton, R. LeRoux, unpubl. data).

In this study, we characterize the movement patterns of nine adult female hawksbills within the Hawaiian Islands. Post-nesting movements to foraging areas are described to illustrate habitat use and offer recommendations for management and conservation of this endangered species.

\section{MATERIALS AND METHODS}

Argos satellite-linked transmitters, ST-3, ST14 (1 watt), and ST-20 (model A-1010, 1/2 watt), manufactured by Telonics, Inc. (Mesa, Arizona), were safely and securely attached with polyester resin and fiberglass cloth to the carapaces of nine female hawksbill turtles following the procedures described by Balazs et al. (1996) and Schroeder et al. (2000). The two ST-3 and six ST-14 transmitters each weighed $750 \mathrm{~g}$ and measured 17 by 10 by 3.5 $\mathrm{cm}$ with the Tygon-protected antenna extending $13 \mathrm{~cm}$ from the top of the transmitter. Transmitters were programmed with either a $6 \mathrm{hr}$ on, $6 \mathrm{hr}$ off duty cycle or a $9 \mathrm{hr}$ on, $3 \mathrm{hr}$ off duty cycle. Units were turned on at a time computed to synchronize with optimum satellite overpass coverage. The single ST-20 transmitter, programmed with a duty cycle of $6 \mathrm{hr}$ on and $48 \mathrm{hr}$ off, weighed 276 $\mathrm{g}$ and measured 6.0 by 12.3 by $2.8 \mathrm{~cm}$.

After completing nesting and before returning to the ocean, each turtle was carefully confined in a prone position inside a portable plywood pen while the satellite tag was attached to the carapace. Transmitters were attached to four hawksbills nesting at Kamehame on the island of Hawai'i (two in August 1995 and two in August 1996) and five hawksbills nesting on the island of Maui at the following beaches: Keālia (1997, 2005), Kawililipoa (1998, 1999), and Oneloa (2004). Size of the turtles was measured in centimeters as straight carapace length (SCL) and/or curved carapace length (CCL).

All deployed transmitters sent data to polar-orbiting NOAA satellites carrying Argos receivers (CLS America, http://www .clsamerica.com). Argos locations were calculated by measuring the Doppler shift on the transmitter signals, which is explained at the CLS America, Inc. (2007) website http:// www.argos-system.org/. Positional accuracy is defined by Argos as follows ( $\mathrm{LC}=$ location code): LC 3, within $150-350 \mathrm{~m}$ to the given location; LC 2, within 350-500 m; LC 1, within $500-1,000 \mathrm{~m}$; and LC $0,>1,000 \mathrm{~m}$. LC A and LC B have no assigned value for accuracy, and $L C Z$ positions were rejected due to their calculation with less than two signals received during the satellite pass. Positions were considered unacceptable if: (1) they were located on land, (2) the speed traveled between two locations was over $5 \mathrm{~km} / \mathrm{hr}$, or (3) the position made a turn greater than 90 degrees in less than a $24-\mathrm{hr}$ period. Decisions for excluding a position were subjective based on these criteria.

The best daily location and the great circle equation with the WGS84 ellipsoid were used to compute distance traveled (Bowditch 1995, Wessel and Smith 1998). Speed (kilometers per hour) was calculated as the distance traveled between adjacent positions divided by the time spent traveling that distance. Speed over the total track was averaged, and the mean speed of transit was recorded. When available, LCs of $0,1,2$, or 3 were used for distance and speed calculations; when unavailable, estimated distance and speed were calculated using the beginning and end points and the most likely route taken by the turtle, which was indicated by the data for each track. The end of a track was determined either by the last Argos position or when positional locations clustered in one general area 


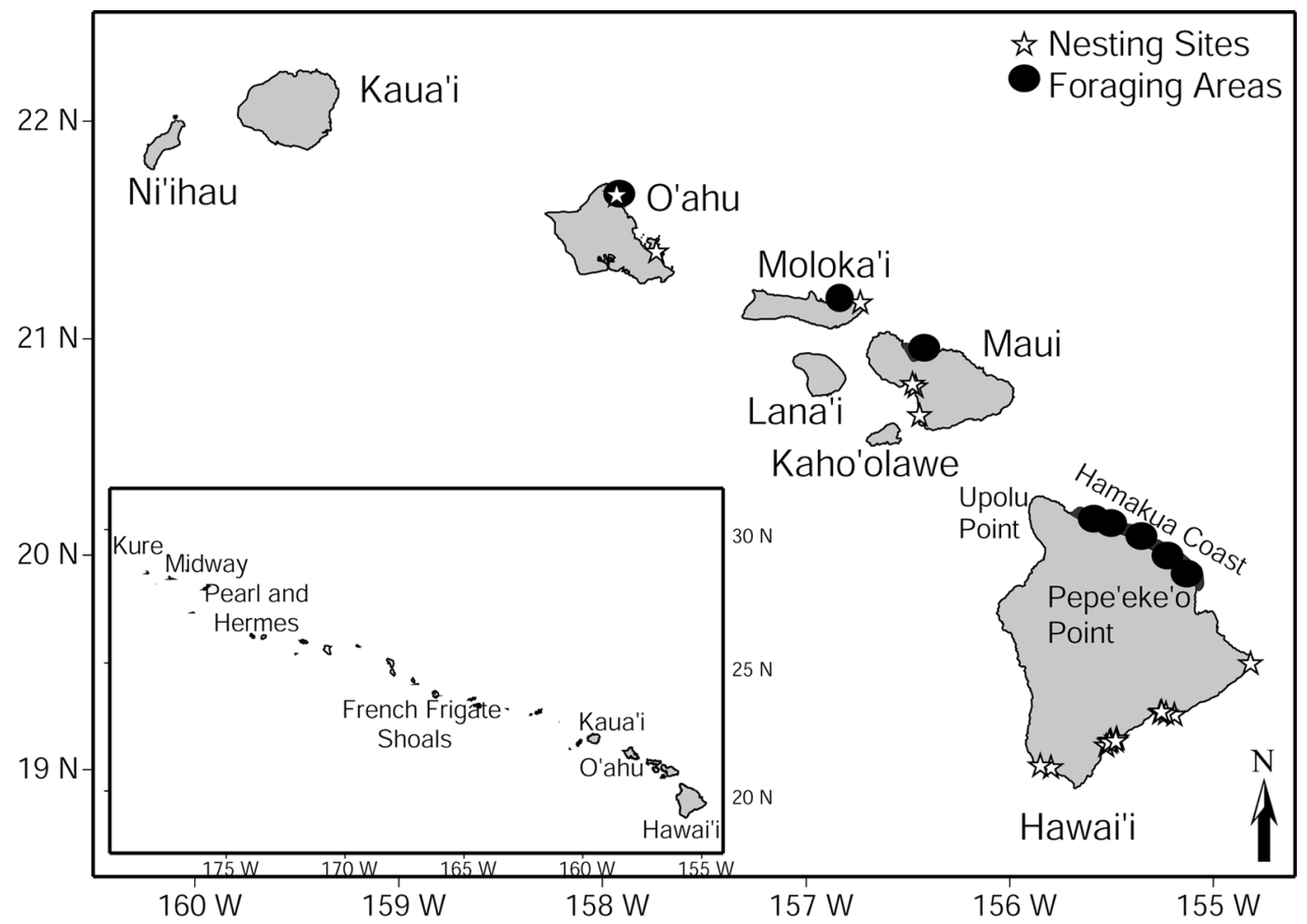

FIGURE 1. Distribution of foraging areas (indicated by black dots) as determined by satellite tracking of nine hawksbills from 1995 to 2005 . Open stars indicate nesting sites. The entire Hawaiian Archipelago is in the inset for scale.

for more than 1 month. The earliest date at an end point was considered the end date for distance and speed calculations. Home-range area in square kilometers was determined for three of the nine tracks using a simplified minimum convex polygon analysis of the foraging area data scatter, using only LC 2 and LC 3 data. Only three tracks had data sufficiently accurate for analysis.

Average dive time in a $12 \mathrm{hr}$ period and time of last dive were collected and transmitted by the ST-3 and ST-14 transmitters. Average dive time and time of last dive were converted into minutes using the formula given by Argos (data times 2 divided by 60). A mean was calculated for each of these variables to provide an index for each turtle during the inactive periods (when the turtle was foraging, resting, or during the internesting period) and the transit period (defined by the date the turtle started moving away from the nesting beach until the date it arrived at the foraging/resting area, or the end data).

\section{RESULTS}

Hawksbill foraging areas in Hawai'i based on these satellite tracking results are shown in Figure 1 along with known hawksbill nesting beaches. Six of the nine hawksbills moved to the northeastern shore of the Hāmākua Coast on the island of Hawaic $i$. The other three individuals traveled to different island foraging areas. The turtles traveled distances ranging from 90 to $345 \mathrm{~km}$, taking between 5 and 18 days to complete the transit (Table 1).

The mean duration of the last dive had a 
TABLE 1

Distance and Duration of Post-nesting Hawksbill Movement from Nesting Beaches on the Islands of Hawai' $i$ and Maui to their Respective Foraging Areas

\begin{tabular}{|c|c|c|c|c|c|c|c|}
\hline Turtle ID & Nesting Site & $\begin{array}{l}\text { SCL or CCL } \\
\text { Carapace } \\
\text { Length }^{a}(\mathrm{~cm})\end{array}$ & $\begin{array}{c}\text { Days } \\
\text { Transmitting }\end{array}$ & $\begin{array}{c}\text { Distance } \\
\text { Traveled } \\
(\mathrm{km})\end{array}$ & $\begin{array}{l}\text { Number } \\
\text { of Days } \\
\text { in Transit }\end{array}$ & $\begin{array}{c}\text { Mean Speed } \\
\text { of Transit } \\
(\mathrm{km} / \mathrm{hr})\end{array}$ & $\begin{array}{l}\text { Foraging Site, } \\
\text { Arrival Location }\end{array}$ \\
\hline $22126-95$ & $\begin{array}{l}\text { Kamehame, } \\
\text { Hawaici }\end{array}$ & 88.1 SCL & 263 & 180 & 10 & 0.8 & $\begin{array}{l}\text { Honoka'a, Hāmākua } \\
\text { Coast }\end{array}$ \\
\hline 22134-95 & $\begin{array}{l}\text { Kamehame, } \\
\text { Hawai'i }\end{array}$ & $83.0 \mathrm{SCL}$ & 277 & 135 & 8 & 0.7 & $\begin{array}{l}\text { Honomu, Hāmākua } \\
\text { Coast }\end{array}$ \\
\hline $24191-96$ & $\begin{array}{l}\text { Kamehame, } \\
\text { Hawai'i }\end{array}$ & 82.4 SCL & 250 & 275 & 12 & 1.0 & $\begin{array}{l}\text { Pa'auilo, Hāmākua } \\
\text { Coast }\end{array}$ \\
\hline $25695-96$ & $\begin{array}{l}\text { Kamehame, } \\
\text { Hawai'i }\end{array}$ & 85.3 SCL & 348 & 345 & 18 & 0.8 & Kahului Bay, Maui \\
\hline $4802-97$ & Keālia, Maui & 87.5 CCL & 142 & 231 & 8 & 1.2 & $\begin{array}{l}\text { Kuku Pt., Hāmākua } \\
\text { Coast }\end{array}$ \\
\hline $4801-98$ & $\begin{array}{l}\text { Kawililipoa, } \\
\text { Maui }\end{array}$ & $89.0 \mathrm{CCL}$ & 300 & 172 & 7 & 1.0 & $\begin{array}{l}\text { Waipi‘o, Hāmākua } \\
\text { Coast }\end{array}$ \\
\hline 25692-99 & $\begin{array}{l}\text { Kawililipoa, } \\
\text { Maui }\end{array}$ & 89.0 CCL & 322 & 90 & 5 & 0.8 & Pelekunu, Moloka'i \\
\hline 19591-04 & Oneloa, Maui & & 372 & 280 & 14 & 0.8 & Mālaekahana, O'ahu \\
\hline $53751-05$ & Keālia, Maui & 86.6 SCL & 312 & 254 & 16 & 0.7 & $\begin{array}{l}\text { Welokā, Hāmākua } \\
\text { Coast }\end{array}$ \\
\hline
\end{tabular}

${ }^{a}$ SCL, straight carapace length; CCL, curved carapace length.

range of $34-77$ min during nontransit periods and a range of 5-35 min during transit periods. The index range for average dive time during a $12 \mathrm{hr}$ period was $14-79 \mathrm{~min}$ for nontransit periods and 5-19 min during transit periods. Home ranges for the three tracks with sufficient data to analyze were estimated to be 0.5 to $2.0 \mathrm{~km}^{2}\left( \pm 1.0 \mathrm{~km}^{2}\right)$.

Three turtles nesting at Kamehame, island of Hawai'i, two turtles nesting at Keālia, Maui, and one from Kawililipoa, Maui, traveled to the Hāmākua Coast of the island of Hawai'i (Figure 2A-F). All turtles followed the coastlines closely whenever possible. Two of the Kamehame hawksbills traveled in a counterclockwise direction around Cape Kumukahi, taking the shortest route around the island of Hawai' $i$ to foraging areas on the Hāmākua Coast (Figure 2A,B). One Kamehame post-nesting hawksbill traveled in a clockwise direction around the island of $\mathrm{Ha}-$ wai' $i$, around the southern tip of the island, north along the west coast and then around the northern tip of the island before arriving at the foraging area near $\mathrm{Pa}^{6}$ auilo on the Hāmākua Coast (Figure 2C).

All three hawksbills that traveled to the Hāmākua Coast from their nesting beaches on Maui took similar paths. They followed the southwest coast of Maui to Kanaloa Point, at which time they traversed across the 'Alenuihāhā Channel (Figure 2D-F). The hawksbills deflected southward during their channel transit. After reaching the coast of the island of Hawai' $i$ near Kohala or 'Upolu Point, the turtles continued in a clockwise fashion around the island to a foraging site along the Hāmākua Coast.

Three of the turtles tracked did not travel to the Hāmākua Coast of the island of Hawaici. One hawksbill traversed from Kamehame, island of Hawai' $i$, in a clockwise fashion crossing the "Alenuihāhā Channel to continue along the north coast of Maui to a foraging area on the western side of Kahului Bay, Maui (Figure 3A). Another traveled from Kawililipoa, Maui, to a final foraging area of Pelekunu, Moloka'i (Figure 3B). The 

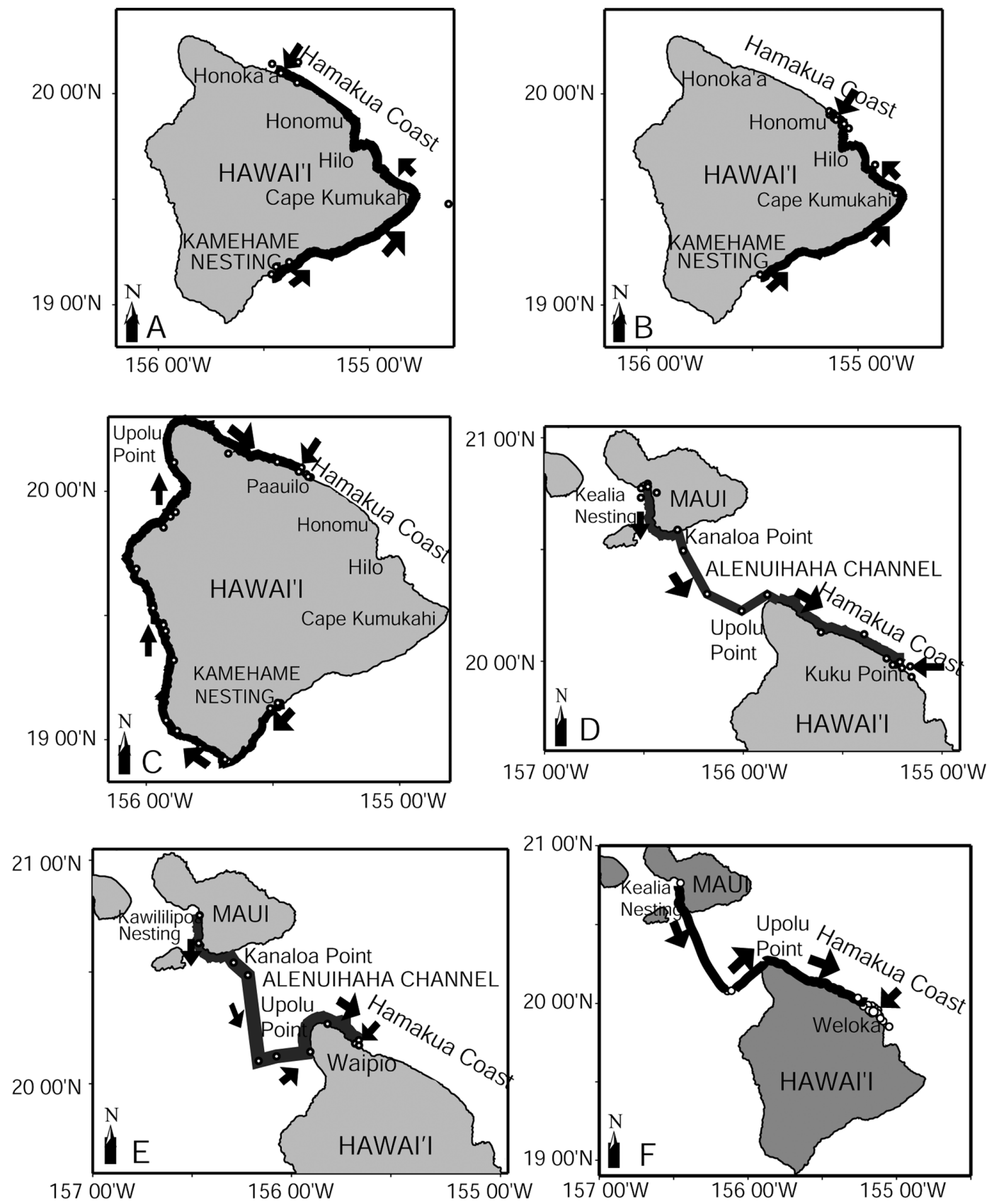

Figure $2 A-F$. Post-nesting movement of six hawksbill turtles from nesting beaches to foraging areas on the Hāmākua Coast of the island of Hawai'i. (A) ID 22126: traveled $180 \mathrm{~km}$ in a total of 10 days between Kamehame nesting beach to Honoka'a; $(B)$ ID 22134: traveled $135 \mathrm{~km}$ in 8 days between Kamehame nesting beach to Honomū; $(C)$ ID 24191 : traveled $275 \mathrm{~km}$ in 12 days between the Kamehame nesting beach and Pa'auilo; (D) ID 4802: traveled $241 \mathrm{~km}$ in 8 days between the Keālia, Maui, nesting beach and Kuku Point; (E) ID 4801: traveled 172 km in 7 days between Kawililipoa Beach, Maui, and Waipi'o; $(F)$ ID 53751: traveled $254 \mathrm{~km}$ in 16 days between the Keālia, Maui, nesting beach and Welokā. 

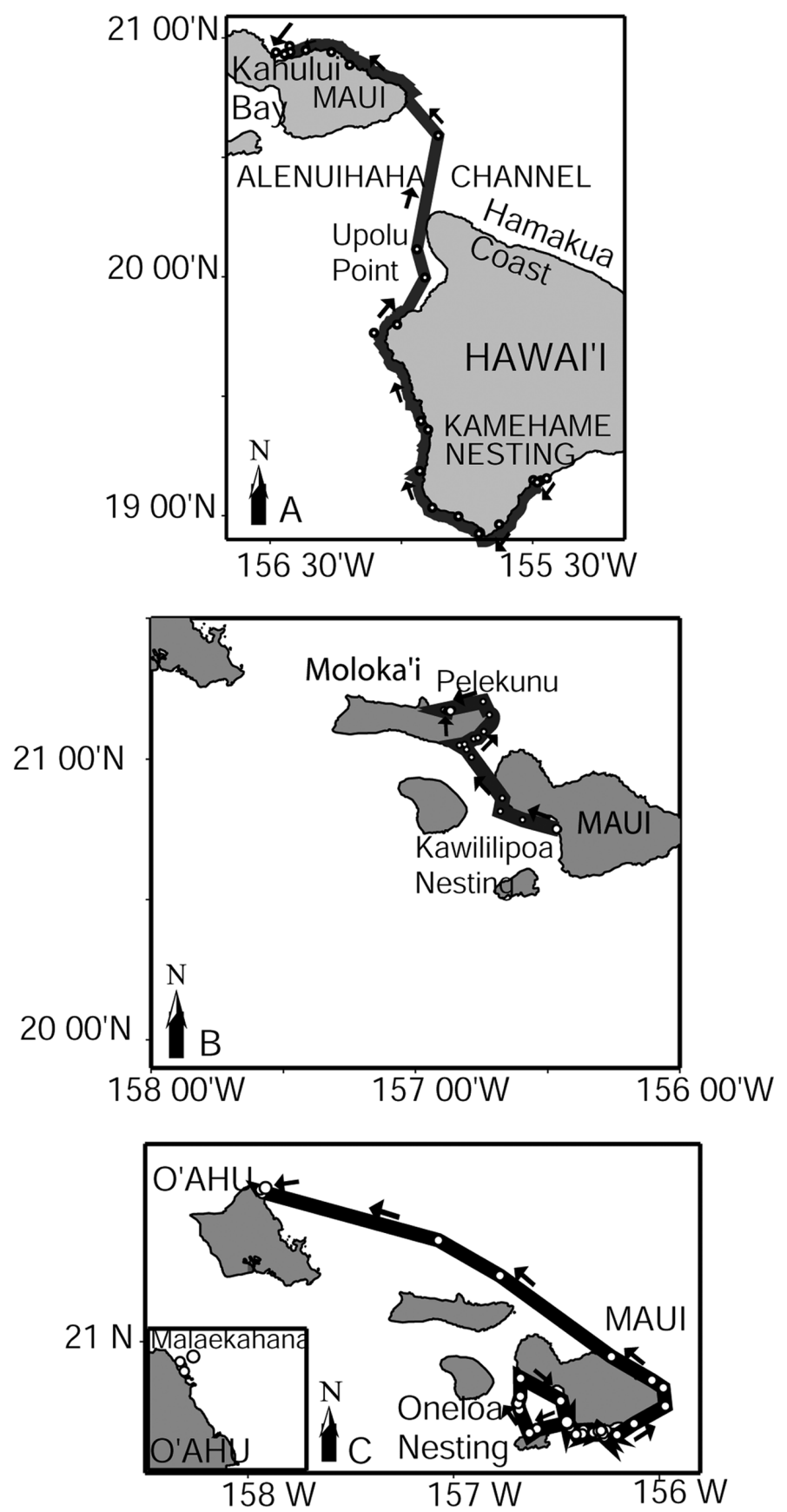

Figure 3A-C. Post-nesting movement of three hawksbill turtles from nesting beaches to different foraging areas. $(A)$ ID 25695: traveled $345 \mathrm{~km}$ in 18 days from Kamehame, island of Hawai' $\mathrm{i}$, to Kahului, Maui; (B) ID 25692: traveled 90 $\mathrm{km}$ in 5 days from Kawililipoa, Maui, to Pelekunu, Moloka'i; (C) ID 19591: traveled $280 \mathrm{~km}$ in 14 days from Oneloa, Maui, to Mālaekahana, O’ahu. 
third turtle used a more circuitous route, completing a 104-km loop returning to nest one last time before heading to her foraging area near Goat Island, Mālaekahana, on the island of $\mathrm{O}^{\prime}$ ahu (Figure $3 C$ ).

\section{DISCUSSION}

Hawai'i, as an isolated archipelago in the middle of the North Pacific Ocean, is situated over $4,800 \mathrm{~km}$ from the nearest major landmass. Transpacific movements have been documented in other sea turtle species such as leatherbacks (Dermochelys coriacea) and loggerheads (Caretta caretta) via tag returns and satellite tracking (Resendiz et al. 1998, Polovina et al. 2004, Benson et al. 2007). Green turtles also migrate long distances, but solely within Hawai'i. Seasonally, green turtles travel from foraging areas in the main islands to mate and nest at French Frigate Shoals in the Northwestern Hawaiian Islands (Balazs and Ellis 2000). Hawksbills, however, are only rarely found in the Northwestern Hawaiian Islands and then only as stranded or injured, perhaps suggesting pelagic waifs. The Northwestern Hawaiian Islands are now part of a protected marine sanctuary known as the Papahānaumokuākea Marine National Monument, but very few of the hawksbill nesting sites are protected in a similar fashion. Organizations on Maui and the island of Hawai' $\mathrm{i}$ have volunteers monitor nesting beaches; this is not done on $\mathrm{O}^{\prime} \mathrm{ahu}$ or Moloka' $\mathrm{i}$. However, in Hawai' $i$, all sea turtles are protected under the Endangered Species Act and under $\mathrm{Ha}$ wai'i State law. Hawai'i also has a sea turtle public outreach and education system, in which both federal and state officials cooperate to educate the public on proper viewing of sea turtles.

During the decade of this study, nine postnesting Hawaiian hawksbills were tracked moving to four different Hawaiian Islands. Movement distances for these turtles were relatively short, between 90 and $345 \mathrm{~km}$. These data are comparable with the distances and time spent traveling by post-nesting hawksbills in the Seychelles (Mortimer and Balazs 2000). Hawksbills tracked from Barbados (Horrocks et al. 2001), Puerto Rico
(Hillis-Star et al. 2000, van Dam et al. 2008), Australia (Miller et al. 1998), and the Solomon Islands (Vaughan and Spring 1980) have shown that the species is capable of long-distance movements $(>2,000 \mathrm{~km})$, yet Hawaiian hawksbills were not found to make this type of movement. The dive duration data indicate that hawksbills spend more time underwater during nontransit periods (resting, foraging, and internesting) than when they are actively moving between nesting and foraging areas. This behavior is similar to that of green turtles in Hawai' $\mathrm{i}$ (Balazs 1994, Balazs and Ellis 2000).

On completion of post-nesting movements to a coastal area in the main Hawaiian Islands, most satellite transmissions continued for 2-6 months, confirming the residency of each turtle at its foraging area. The end of transmissions was believed to have usually been caused by drainage of the transmitter battery over time or from antenna damage or wear sustained while the turtle was resting in areas with coral and rocky overhangs. It is difficult to ascertain the exact cause of transmitter cessation. Manufacturers provide a theoretical estimated operational life for batteries used in the transmitters. However, when a transmitter stops giving data within a few weeks to a month of arriving in a foraging area, it is often thought that this is due to antenna wear. Evidence for this assumption comes from transmitters that have been recovered from green and hawksbill turtles, where antenna wear and missing antennae are apparent (Schroeder and Balazs 2000).

Argos positional data based on the Doppler shift do not have as precise accuracy as GPS transmitters (minimum of $150 \mathrm{~m}$ versus $5 \mathrm{~m}$ [Yasuda and Arai 2005]). However, the data are accurate enough for general tracking, and higher-accuracy positions (LC 1, 2, and 3 ) allow a relatively good estimate of the position of the turtle. High-accuracy data were very limited within foraging areas; hence only three of the tracks could be used for home range estimation. Based on the data collected for these three tracks (LC 2 and 3 data), estimates of hawksbill home ranges in Hawai'i were calculated to be 0.5 to $2.0 \mathrm{~km}^{2}$ $\left( \pm 1.0 \mathrm{~km}^{2}\right)$. These home ranges were slightly 
larger than hawksbill home ranges found in the Caribbean area $\left(<0.5 \mathrm{~km}^{2}\right.$ [van Dam and Diez 1998]). Argos data collected in the Hawaiian foraging areas also indicate that postnesting females use depths of less than $30 \mathrm{~m}$ in the nearshore habitat. It is interesting to note that all of the Hawaiian hawksbills satellite tracked in this study established residency on the north-northeast side of the Islands. In contrast, immature hawksbills have been sighted by divers either on the southsouthwest sides of the Islands, typically in waters less than $30 \mathrm{~m}$ or in very shallow protected areas on the north and northeast sides (Balazs 1978a, Keuper-Bennett and Bennett 2002; pers. obs. of authors). This difference in foraging location may be a mechanism to separate the food and space resources of the juvenile and adult stages of the hawksbill turtle in Hawai'i. These preliminary data may also reflect diver preference for calm ocean conditions and accessible coral reef ecosystems, hence additional research is needed on this topic.

Six of the nine Hawaiian hawksbills migrated to the Hāmākua Coast of the island of Hawai' $i$. These data indicate that the Hāmākua Coast is important habitat for the hawksbill in the Hawaiian Islands. The foraging area on the Hāmākua Coast spans from Pololū Valley to Pepe'ekeo Point, covering a distance of $112 \mathrm{~km}$ (Figure 1), and although each turtle may only use $1 \mathrm{~km}^{2}$, appropriate management measures for the whole coast should be considered for the conservation of Hawai'i's hawksbill population.

In conclusion, hawksbills in Hawai'i are a small population and more information is needed to determine their conservation status to aid in recovery. The results of this study suggest that the post-nesting movements of the Hawaiian hawksbill are relatively shortranged; therefore, management of resources within the State of Hawai'i will be key in the long-term survival of this species. Focused underwater hawksbill surveys and further study of their forage and habitat needs are necessary to address the distribution and abundance of Hawaiian hawksbills. Surveys along the Hāmākua Coast should be conducted to assess the status of the habitat for conservation and management purposes. Surveys of all the foraging areas should also be conducted to identify similarities and differences to better understand the hawksbill's requirements in the Hawaiian Islands.

\section{ACKNOWLEDGMENTS}

We thank George Antonelis, Marc Rice, Stacy Hargrove, Shawn K. K. Murakawa, Jerry Wetherall, Karen Frutchey, and two anonymous reviewers for their comments. We thank the coordinators and all of the volunteers who worked for the Hawai' $i \mathrm{Vol}-$ canoes National Park; Hawksbill Recovery Project, in their monitoring of hawksbill nesting on the island of Hawai' $i$, which allowed us success in our attachments on that island. We extend our thanks also to Skippy Hau of the Maui Department of Land and Natural Resources, Division of Aquatic Resources; Glynnis Nakai of the U.S. Fish and Wildlife Service, Refuge Manager of the Keālia National Wildlife Refuge; Steve Williams and other Maui Dawn Patrol volunteers; and a special thanks to Suzanne Canja and to the Hawai'i Wildlife Fund, who monitored the hawksbill nesting sites on Maui and contributed to successful satellite deployments.

\section{Literature Cited}

Balazs, G. H. 1978a. A hawksbill turtle in Kaneohe Bay, Oahu. 'Elepaio 38:128-129. 1978b. Terrestrial critical habitat for sea turtles under United States jurisdiction in the Pacific region. 'Elepaio 39:37-41.

. 1994. Homeward bound: Satellite tracking of Hawaiian green turtles from nesting beaches to foraging pastures. Pages 205-208 in B. A. Schroeder and B. E. Witherington, comps. Proceedings of the 13th Annual Symposium on Sea Turtle Biology and Conservation. NOAA Tech. Memo. NMFS-SEFSC-341.

Balazs, G. H., W. C. Dudley, L. E. Hallacher, J. P. Coney, and S. K. Koga. 1994. Ecology and cultural significance of sea turtles at Punalu'u, Hawaii. Pages 10-13 in K. A. Bjorndal, A. B. Bolten, D. A. Johnson, and P. J. Eliazar, comps. Pro- 
ceedings of the 14th Annual Symposium on Sea Turtle Biology and Conservation. NOAA Tech. Memo. NMFS-SEFSC-351.

Balazs, G. H., and D. M. Ellis. 2000. Satellite telemetry of migrant male and female green turtles breeding in the Hawaiian Islands. Pages 3-5 in F. A. Abreu-Grobois, R. Briseño-Dueñas, R. Márquez-Millán, L. Sarti-Martínez, comps. Proceedings of the 18th Annual Symposium on Sea Turtle Biology and Conservation. NOAA Tech. Memo. NMFS-SEFSC-436, Suppl.

Balazs, G. H., R. K. Miya, and S. C. Beavers. 1996. Procedures to attach a satellite transmitter to the carapace of an adult green turtle, Chelonia mydas. Pages 21-26 in J. A. Keinath, B. E. Barnard, J. A. Musick, and B. A. Bell, comps. Proceedings of the 15th Annual Symposium on Sea Turtle Biology and Conservation. NOAA Tech. Memo. NMFS-SEFSC-537.

Bass, A. L. 1999. Genetic analysis to elucidate the natural history and behavior of hawksbill turtles (Eretmochelys imbricata) in the wider Caribbean: A review and re-analysis. Chelonian Conserv. Biol. 3:195-199.

Bell, I. P., J. D. Miller, K. A. Dobbs, and C. J. Limpus. 1999. Hawksbill turtle movements in the coral sea. Page 95 in F. A. AbreuGrobois, R. Briseño, R. Márquez, and L. Sarti, comps. Proceedings of the 18th International Symposium on Sea Turtle Biology and Conservation. NOAA Tech. Memo. NMFS-SEFSC-436.

Benson, S. R., P. H. Dutton, C. Hitipeuw, B. Samber, J. Bakarbessy, and D. Parker. 2007. Post-nesting migrations of leatherback turtles (Dermochelys coriacea) from Jamursba-Medi, Bird's Head Peninsula, Indonesia. Chelonian Conserv. Biol. 6:150-154.

Bowditch, N. 1995. The American practical navigator: An epitome of navigation. $\mathrm{Na}$ tional Imagery and Mapping Agency. Publ. No. 9. Bethesda, Maryland.

Buck, P. H. 1957. Arts and crafts in Hawaii. Bernice P. Bishop Mus. Spec. Publ. 45.

Byles, R. A., and Y. B. Swimmer. 1994. Postnesting migration of Eretmochelys imbricata in the Yucatan Peninsula. Page 202 in K. A.
Bjorndal, A. B. Bolten, D. A. Johnson, and P. J. Eliazar, comps. Proceedings of the 14th Annual Symposium on Sea Turtle Biology and Conservation. NOAA Tech. Memo. NMFS-SEFSC-351.

Campbell, L. M. 2003. Contemporary culture, use, and conservation of sea turtles. Pages 307-338 in P. L. Lutz, J. A. Musick, and J. Wyneken, eds. Biology of sea turtles. Vol. 2. CRC Press, Boca Raton, Florida.

Canin, J. 1991. International trade aspects of the Japanese hawksbill shell ('Bekko') industry. Mar. Turtle Newsl. 54:17-21.

Carrillo, E., G. J. W. Webb, and S. C. Manolis. 1999. Hawksbill turtles (Eretmochelys imbricata) in Cuba: An assessment of the historical harvest and its impacts. Chelonian Conserv. Biol. 3:264-280.

Chaloupka, M., T. M. Work, G. H. Balazs, S. K. K. Murakawa, and R. Morris. 2008. Cause-specific temporal and spatial trends in green sea turtle strandings in the Hawaiian Archipelago (1982-2003). Mar. Biol. (Berl.) 154:887-898.

CLS America, Inc. 2007. Argos system. http:// www.clsamerica.com. 1441 McCormick Drive, Suite 1050, Largo, Maryland 20774.

Fussy, A., P. Pommier, C. Lumbroso, and L. de Haro. 2007. Chelonitoxism: New case reports in French Polynesia and review of the literature. Toxicon 49:827-832.

Groshens, E. B., and M. R. Vaughan. 1994. Post-nesting movements of hawksbill sea turtles from Buck Island Reef National Monument, St. Croix, USVI. Page 69 in B. A. Schroeder and B. E. Witherington, comps. Proceedings of the 13th Annual Symposium on Sea Turtle Biology and Conservation. NOAA Tech. Memo. NMFS-SEFSC-341.

Hainshwang, T., and L. Leggio. 2006. The characterization of tortoise shell and its imitations. Gems Gemology 42 (1): 36-52.

Hillis, Z.-M. 1994. The hawksbill turtles of Buck Island Reef National Monument: A shared resource of the Caribbean. Pages 59-61 in K. A. Bjorndal, A. B. Bolten, D. A. Johnson, and P. J. Eliazar, comps. Proceedings of the 14th Annual Sympo- 
sium on Sea Turtle Biology and Conservation. NOAA Tech. Memo. NMFSSEFSC-351.

Hillis-Starr, Z., M. Coyne, and M. Monaco. 2000. Buck Island and back: Hawksbill turtles make their move. Page 159 in H. J. Kalb and T. Wibbels, comps. Proceedings of the 19th Annual Symposium on Sea Turtle Biology and Conservation. NOAA Tech. Memo. NMFS-SEFSC-443.

Hilton-Taylor, C., comp. 2000. 2000 IUCN Red list of threatened species. IUCN, Gland, Switzerland, and Cambridge, United Kingdom.

Horrocks, J. A., L. A. Vermeer, B. Kreuger, M. Coyne, B. A. Schroeder, and G. H. Balazs. 2001. Migration routes and destination characteristics of post-nesting hawksbill turtles satellite-tracked from Barbados, West Indies. Chelonian Conserv. Biol. 4:107-114.

Kaeppler, A. L. 1978. "Artificial curiosities": An exposition of native manufactures collected on the three Pacific voyages of Captain James Cook, R.N. Bernice P. Bishop Mus. Spec. Publ. 65.

Katahira, L. K., C. M. Forbes, A. H. Kikuta, G. H. Balazs, and M. Bingham. 1994. Recent findings and management of hawksbill turtle nesting beaches in Hawaii. Page 69 in K. A. Bjorndal, A. B. Bolten, D. A. Johnson, and P. J. Eliazar, comps. Proceedings of the 14th Annual Symposium on Sea Turtle Biology and Conservation. NOAA Tech. Memo. NMFS-SEFSC-351.

Keuper-Bennett, U., and P. A. Bennett. 2002. Home sweet home: Aspects of green turtle and hawksbill presence in their feeding, resting and cleaning areas off Honokowai, West Maui, Hawaii (1989-1999). Pages 57-59 in A. Mosier, A. Foley, and B. Brost, comps. Proceedings of the 20th Annual Symposium on Sea Turtle Biology and Conservation. NOAA Tech. Memo. NMFS-SEFSC-477.

King, C. K., W. Gilmartin, S. Hau, H. Bernard, S. Canja, G. Nakai, M. J. Grady, S. Williams, and A. G. Hebard. 2007. Nesting hawksbill turtles (Eretmochelys imbricata) on the island of Maui, Hawaii from
1996-2003. Pages 134-135 in R. B. Mast, B. J. Hutchinson, and A. H. Hutchinson, comps. Proceedings of the 24th Annual Symposium on Sea Turtle Biology and Conservation. NOAA Tech. Memo. NMFS-SEFSC-567.

Limpus, C. J., and J. D. Miller. 2008. Australian turtle project population dynamics project. The State of Queensland, Environmental Protection Agency.

Mangel, J. C., H. Bernard, S. Canja, S. Hau, K. Smith, and S. Williams. 2000. Summary of hawksbill turtles (Eretmochelys imbricata) nesting on Maui, Hawaii from 1991 to 1996. Pages 283-284 in H. J. Kalb and T. Wibbels, comps. Proceedings of the 19th Annual Symposium on Sea Turtle Biology and Conservation. NOAA Tech. Memo. NMFS-SEFSC-443.

McClenachan, L., J. B. C. Jackson, and M. J. H. Newman. 2006. Conservation implications of historic sea turtle nesting beach loss. Front. Ecol. Environ. 4:290296.

Meylan, A. 1988. Spongivory in hawksbill turtles: A diet of glass. Science (Washington, D.C.) 239:393-395.

- 1999. International movements of immature and adult hawksbill turtles (Eretmochelys imbricata) in the Caribbean region. Chelonian Conserv. Biol. 3:200-224.

Miller, J. D., K. A. Dobbs, C. J. Limpus, N. Mattocks, and A. M. Landry Jr. 1998. Long-distance migrations by the hawksbill turtle, Eretmochelys imbricata, from northeastern Australia. Wildl. Res. 25:89-95.

Mortimer, J. A., and G. H. Balazs. 2000. Post-nesting migrations of hawksbill turtles in the granitic Seychelles and implications for conservation. Pages 22-26 in H. J. Kalb and T. Wibbels, comps. Proceedings of the 19th Annual Symposium on Sea Turtle Biology and Conservation. NOAA Tech. Memo. NMFS-SEFSC-443.

Mortimer, J. A., M. Donnelly, A. B. Meylan, and P. A. Meylan. 2007. Critically endangered hawksbill turtles: Molecular genetics and the broad view of recovery. Mol. Ecol. 16:3516-3517.

MSNBC News Service. 2007. Poachers with 
nearly 300 sea turtles nabbed. World News, World Environment. 30 March. http://www.msnbs.msn.com/id/17872561.

National Marine Fisheries Service (NMFS) and U.S. Fish and Wildlife Service (USFWS). 1998. Recovery plan for U.S. Pacific populations of the Hawksbill Turtle (Eretmochelys imbricata). National Marine Fisheries Service, Silver Spring, Maryland.

Polovina, J. J., G. H. Balazs, E. A. Howell, D. M. Parker, M. P. Seki, and P. H. Dutton. 2004. Forage and migration habitat of loggerhead (Caretta caretta) and olive ridley (Lepidochelys olivacea) sea turtles in the central North Pacific Ocean. Fish. Oceanogr. 13:36-51.

Pukui, M. K., and S. H. Elbert. 1992. New pocket Hawaiian dictionary with a concise grammar and given names in Hawaiian. University of Hawai'i Press, Honolulu.

Resendiz, A., B. Resendiz, W. J. Nichols, J. A. Seminoff, and N. Kamezaki. 1998. First confirmed east-west transpacific movement of a loggerhead sea turtle, Caretta caretta, released in Baja California, Mexico. Pac. Sci. 52:151-153.

Rose, R. G., S. Conant, and E. P. Kjellgren. 1993. Hawaiian standing kahili in Bishop Museum: An ethnological and biological analysis. J. Polynesian Soc. 102:273-304.

Schroeder, B. A., and G. H. Balazs. 2000. Design and field testing of an internal helix antenna satellite transmitter for sea turtles. Pages 30-31 in H. J. Kalb and T. Wibbels, comps. Proceedings of the 19th Annual Symposium on Sea Turtle Biology and
Conservation. NOAA Tech. Memo. NMFS-SEFSC-443.

Schroeder, B., G. Balazs, and M. Rogers. 2000. ST-14 sea turtle satellite transmitter attachment instructions. Prepared specifically for Pacific Region Hawksbill Research-Satellite Tracking Project 2000 and Caribbean Hawksbill ResearchSatellite Tracking Project 1998/1999/ 2000. National Marine Fisheries Service, Silver Spring, Maryland.

Troëng, S., P. H. Dutton, and D. Evans. 2005. Migration of hawksbill turtles, Eretmochelys imbricata, from Tortuguero, Costa Rica. Ecography 28:394-402.

van Dam, R. P., and C. E. Diez. 1998. Home range of immature hawksbill turtles (Eretmochelys imbricata, Linnaeus) at two Caribbean islands. J. Exp. Mar. Biol. Ecol. 220:15-24.

van Dam, R. P., C. E. Diez, G. H. Balazs, L. A. Cólon, W. O. McMillan, and B. Schroeder. 2008. Sex-specific migration patterns of hawksbill turtles breeding at Mona Island, Puerto Rico. Endang. Species Res. 4:85-94.

Vaughan, P., and S. Spring. 1980. Long distance hawksbill recovery. Mar. Turtle Newsl. 16:6-7.

Wessel, P., and W. H. F. Smith. 1998. New, improved version of Generic Mapping Tools released. EOS Trans. Am. Geophys. U. 79 (47).

Yasuda, T., and N. Arai. 2005. Fine-scale tracking of marine turtles using GPSArgos PTTs. Zool. Sci. (Tokyo) 22:547553 . 